\title{
Managing emerging transnational public health security threats: lessons learned from the 2014 West African Ebola outbreak
}

\author{
Aaron M. Wendelboe ${ }^{1 *}$ D, Micah McCumber ${ }^{1}$, Julie Erb-Alvarez ${ }^{3,5}$, Nicholas Mould ${ }^{2}$, Richard W. Childs ${ }^{4}$ \\ and James L. Regens ${ }^{2}$
}

\begin{abstract}
Background: Pandemics pose significant security/stability risks to nations with fragile infrastructures. We evaluated characteristics of the 2014 West African Ebola outbreak to elucidate lessons learned for managing transnational public health security threats.

Methods: We used publically available data to compare demographic and outbreak-specific data for Guinea, Sierra Leone, and Liberia, including key indicator data by the World Health Organization. Pearson correlation statistics were calculated to compare country-level infrastructure characteristics with outbreak size and duration.

Results: Hospital bed density was inversely correlated with longer EVD outbreak duration ( $r=-0.99)$. Country-specific funding amount allocations were more likely associated with number of incident cases than the population at-risk or infrastructure needs. Key indicators demonstrating challenges for Guinea included: number of unsafe burials, percent of EVD-positive samples, and days between symptom onset and case hospitalization. Sierra Leone's primary key indicator was the number of districts with $\geq 1$ security incident. Liberia controlled their outbreak before much of the key-indicator data were collected.
\end{abstract}

Conclusion: Many of the country-level factors, particularly the WHO key indicators were associated with controlling the epidemic. The infrastructure of countries affected by communicable diseases should be assessed by international political and public health leaders.

Keywords: Pandemic, Public health, Response, Outbreak investigation, Ebola virus disease

\section{Background}

The nexus between risks posed by infectious disease pandemics to the stability of fragile states and international security was demonstrated dramatically by the largest reported Ebola Virus Disease (EVD) outbreak which occurred in West Africa between 2014 and 2015 [1-5]. Underscoring its severity, the 2014 West African Ebola outbreak was larger than all previous EVD outbreaks combined. The epidemic began in December 2013 and the World Health Organization (WHO) was notified on March 23, 2014. The WHO declared it a public health

\footnotetext{
* Correspondence: Aaron-Wendelboe@ouhsc.edu

${ }^{1}$ Department of Biostatistics and Epidemiology, University of Oklahoma Health Sciences Center, 801 NE 13th St., CHB 323, Oklahoma City, OK 73104, USA

Full list of author information is available at the end of the article
}

emergency of international concern on August 8, 2014 [6]. Further demonstrating the security threat posed by this public health emergency, the United Nations Security Council Resolution 2176 (2014) adopted on September 15, 2014 declared the outbreak was "a threat to international peace and security in the region" [7]. The international community's response acting in cooperation with the immediately affected countries included diagnosing the disease as early as possible, contact tracing, patient isolation and care, infection control, ring vaccination, safe burial practices, and public education (e.g., messages on billboards and radio describing symptoms, hand hygiene, school closures, and avoiding close contact to prevent transmission). Indeed, many of these factors comprise the majority of the WHO Ebola Situation Reports' key performance indicators [8]. The outbreak officially ended

(C) The Author(s). 2019 Open Access This article is distributed under the terms of the Creative Commons Attribution 4.0 International License (http://creativecommons.org/licenses/by/4.0/), which permits unrestricted use, distribution, and 
on March 29, 2016. Ten countries were directly impacted, three of which experienced significant outbreaks (Guinea, Liberia, and Sierra Leone), while seven countries reported one or more EVD cases without widespread human-to-human transmission (Italy, Mali, Nigeria, Senegal, Spain, the UK, and the US) $[9,10]$.

We aim to systematically examine country-specific factors within the context of the larger global pandemic with the greatest emphasis on Guinea, Liberia, and Sierra Leone. Specifically, we 1) conduct a quantitative analysis of country-specific factors in Guinea, Liberia, and Sierra Leone and 2) conduct a qualitative analysis of patterns of disease incidence and transmission among all countries with $\geq 1$ case of EVD to draw lessons learned from the 2014 West African Ebola outbreak for managing emerging transnational health security threats.

\section{Results}

\section{Overall summary}

By March 30, 2016, WHO reported 28,646 cases and 11,323 deaths from the 2014 West African Ebola Outbreak, [9] with an overall case fatality rate of $39.5 \%$. Cases were observed in 10 countries across three continents (Africa, Europe, and North America). Table 1 summarizes the number of cases, deaths, contacts followed, and date the country was first declared Ebola-free. Epidemic curves for the three widely affected countries are shown in Fig. 1 . At the epidemic's peak, the doubling time was 15-20 days for cases in Liberia and 30-40 days for Sierra Leone and Guinea [11]. Although four new confirmed cases were diagnosed in Guinea during March 17-28, the WHO Director-General declared on March 29, 2016 the end of the Public Health Emergency of International Concern regarding the EVD outbreak in West Africa [9].

\section{Outbreak by widely-affected country Guinea}

The first case likely occurred December 26, 2013, but not identified as Ebola until March 21, 2014 [12]. The index case was traced to a two-year-old boy in Meliandou, a village near Gueckedou, Guinea [13]. Evidence suggests his exposure was likely an infected Angolan free-tailed bat $[13,14]$. Although Guinea had the highest case fatality rate (66.7\%, Fig. 2) and was the last to be declared Ebola-free, it had the lowest number of cases among the widely-affected countries. The peak number of weekly cases reported was 526 in November 2014 [15]. Eight (23.5\%) of the 34 prefectures in Guinea did not report any Ebola cases [16]. By March 29, 2016, there were 3811 EVD cases, 2543 deaths [17] (Table 1) and 187 cases among health care workers (HCWs), of which 94 died [18].

\section{Sierra Leone}

The first Sierra Leone case was retrospectively identified as a female guest in the index case's home in Meliandou, Guinea, but returned to Sierra Leone and died in early January 2014 [12]. It was not until April 1, 2014 that Sierra Leone "stepped up vigilance for imported cases when two members of the same family who had died from Ebola virus disease in Guinea were repatriated to Sierra Leone for burial" [12]. By November 2014, EVD had been reported in each district in Sierra Leone [16] and the peak number of weekly cases reported was 1997 [15]. Sierra Leone had the highest number of cases $(14,124)$ but the lowest case fatality rate $(28.0 \%)$. The cumulative number of deaths was 3956 [8] (Table 1) and 303 EVD cases among HCW, of which 221 died [18].

Table 1 Distribution of Cases, Deaths, Contacts, and Date declared Ebola-free

\begin{tabular}{|c|c|c|c|c|c|c|c|}
\hline Country & Cases & Deaths & Case-fatality Rate (\%) & HCW Cases & HCW Deaths & Contacts & Date first Ebola-Free \\
\hline \multicolumn{8}{|l|}{ Widely affected } \\
\hline Guinea & 3811 & 2543 & 66.7 & 187 & 94 & TMTC & December 29, 2015 \\
\hline Sierra Leone & 14,124 & 3956 & 28.0 & 303 & 221 & TMTC & November 7, 2015 \\
\hline Liberia & 10,675 & 4809 & 45.0 & 378 & 192 & TMTC & May 9, 2015 \\
\hline \multicolumn{8}{|l|}{ Limited transmission } \\
\hline Italy & 1 & 0 & 0.0 & 1 & 0 & 19 [18] & July 20, 2015 \\
\hline Mali & 8 & 6 & 75.0 & 2 & 2 & $433[38]$ & January 18, 2015 \\
\hline Nigeria & 20 & 8 & 40.0 & 0 & 0 & $891[22]$ & October 20, 2014 \\
\hline Senegal & 1 & 0 & 0.0 & 0 & 0 & 74 [39] & October 17, 2014 \\
\hline Spain & 1 & 0 & 0.0 & 1 & 0 & 83 [17] & December 2, 2014 \\
\hline United Kingdom & 1 & 0 & 0.0 & 1 & 0 & 55 [8] (+ 177 airplane) & March 10, 2015 \\
\hline United States & 4 & 1 & 25.0 & 3 & 0 & 177 [40] & December 20, 2014 \\
\hline
\end{tabular}

${ }^{a}$ Each of the widely-affected countries was declared Ebola-free and subsequently had a small number of newly detected cases. The first date of being declared Ebola-free is a reasonable marker of when the outbreak was controlled in that country

HCW - Healthcare worker

TMTC - Too many to count 


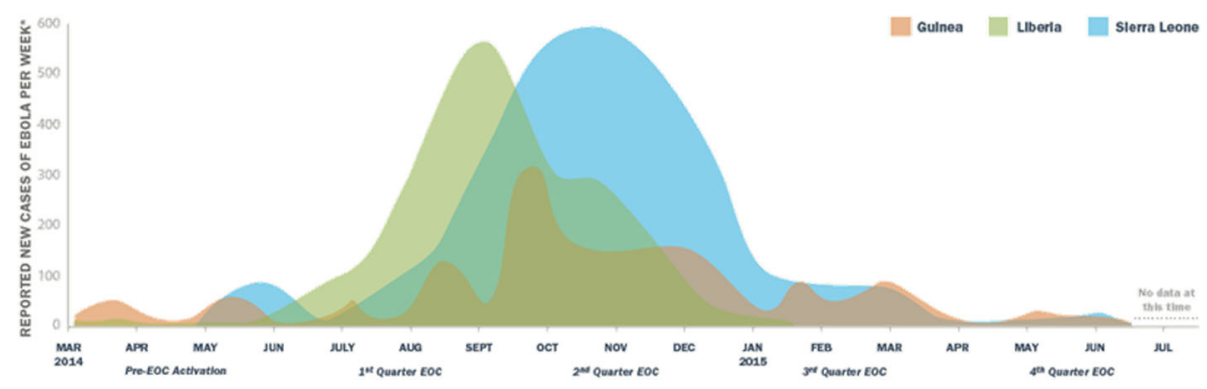

Fig. 1 Epidemic Curve of Ebola Cases in West Africa. Reprinted with permission from CDC, cdc.gov/about/ebola/timeline.html

\section{Liberia}

Ebola was first reported on March 30, 2014 in Lofa's Foya district, [12] which borders Sierra Leone and Guinea. Lofa became the first model area of success when it reported no new cases October-December 2014. Success was attributed to "implementing the full package of control interventions, including community engagement, acceptance, and ownership of the response" [12]. Ultimately there were 10,675 cases and 4809 deaths (case fatality rate $=45 \cdot 0 \%$ ) [8]. All districts in the country reported cases of EVD [16]. Liberia had the highest number of HCW EVD cases $(n=378)$, but fewer deaths $(n=192)$ [18] than Sierra Leone.

\section{Comparison of widely-affected countries}

Table 2 illustrates important demographic differences between these three countries. Guinea's population $(11,474,383)$ is approximately twice Sierra Leone's $(5,743,725)$ and Liberia's $(4,092,310)$, yet has the lowest health and education expenditures and literacy rate. Guinea also has the lowest ethnic diversity.

Generally, we failed to detect correlations between the health indicator data (infant mortality rate, health expenditures as \% of GDP, physician density, and hospital bed density) and EVD-related outcomes (i.e., duration of the EVD outbreak and the EVD-specific mortality rate). The only statistically significant correlation was between outbreak duration and hospital bed density $(r=-0.99$, $p<0.01$ ); fewer hospital beds per 1000 population was correlated with longer EVD outbreak duration.

Country-specific information regarding the distribution of EVD-related financial resources is opaque. Initially, Guinea received approximately half the funding Sierra Leone and Liberia received. According to a WHO budget [19] for July-December 2014, Guinea received $\$ 1,927,993$, Sierra Leone received $\$ 4,471,599$, and Liberia received $\$ 3,711,908$. Nigeria, which ultimately was not widely affected, initially received nearly as much funding $(\$ 1,305,000)$ as Guinea. A WHO financial report covering October 31, 2015 reported the following geographic allocation of donor funds: Guinea 11\%, Liberia 32\%, Sierra Leone 22\%, Regional 33\%, and Other 2\% [20]. By the outbreak's end, approximately $\$ 3.7$ billion had been dedicated to the Ebola response during 2014-2016 [21]. Money allocation more closely correlated with country-specific incident EVD cases than population size. The EVD case and population-at-risk distribution was: Guinea $=13.3 \%$ cases, $53.8 \%$ population-at-risk, Sierra Leone $=49.3 \%$ cases, $27 \cdot 0 \%$ population-at-risk, and Liberia $=37 \cdot 3 \%$ cases, $19.2 \%$ population-at-risk.

Comparing the 10 key indicator data provides limited insights into differences between Guinea and Sierra Leone's country-specific epidemics; the epidemic was largely controlled in Liberia (Fig. 3) by the time they were systematically collected. Three indicators showed worse problems in Guinea (number of unsafe burials,
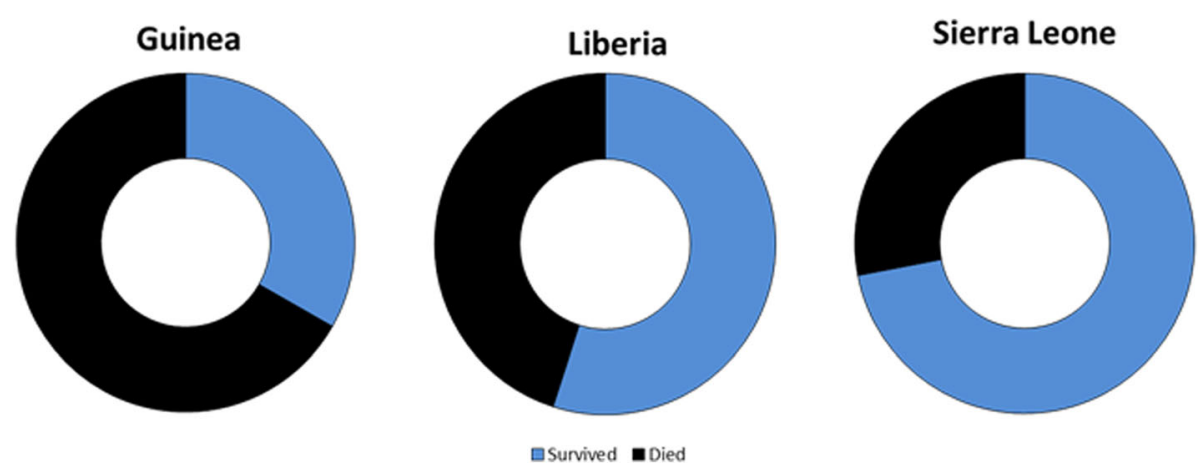

Fig. 2 Case fatality among affected countries as of March 30, 2016 
Table 2 Population Statistics for Guinea, Sierra Leone, and Liberia [41]

\begin{tabular}{|c|c|c|c|}
\hline Characteristic & Guinea & Sierra Leone & Liberia \\
\hline Population & $11,474,383$ & $5,743,725$ & $4,092,310$ \\
\hline Population density per $\mathrm{km}^{2}$ & 40.9 & 79.4 & 40.4 \\
\hline Median age (years) & $18 \cdot 7$ & 19 & $17 \cdot 9$ \\
\hline Infant mortality rate (deaths/1000 live births) & $55 \cdot 24$ & $73 \cdot 3$ & $69 \cdot 19$ \\
\hline Health expenditures (\% of GDP) & 6 & 18.8 & $19 \cdot 5$ \\
\hline Physician density (physicians/1000 population) & $0 \cdot 1$ & 0.02 & 0.01 \\
\hline Hospital bed density (beds/1000 population) & 0.3 & 0.4 & 0.8 \\
\hline Literacy (\% age $15+$ can read and write) & 41 & $43 \cdot 3$ & $60 \cdot 8$ \\
\hline Education expenditures (\% of GDP) & 2.5 & $2 \cdot 9$ & $2 \cdot 8$ \\
\hline Urbanization (\% urban) & $35 \cdot 4$ & $39 \cdot 2$ & $48 \cdot 2$ \\
\hline Religions & $\begin{array}{l}\text { Muslim 85\%, } \\
\text { Christian 8\%, } \\
\text { Indigenous beliefs 7\% }\end{array}$ & $\begin{array}{l}\text { Muslim 60\%, } \\
\text { Christian 10\%, } \\
\text { Indigenous beliefs 30\% }\end{array}$ & $\begin{array}{l}\text { Christian } 85 \cdot 6 \% \text {, } \\
\text { Muslim } 12 \cdot 2 \% \\
\text { Traditional } 0.6 \% \\
\text { Other } 0.2 \% \\
\text { None } 1.4 \%\end{array}$ \\
\hline Ethnic groups & $\begin{array}{l}\text { Peuhl } 40 \% \text {, } \\
\text { Malinke } 30 \% \text {, } \\
\text { Soussou 20\%, } \\
\text { other } 10 \%\end{array}$ & $\begin{array}{l}\text { Temne 35\%, } \\
\text { Mende 31\%, } \\
\text { Limba 8\%, } \\
\text { Kono 5\%, } \\
\text { Kriole 2\%, } \\
\text { Mandingo 2\%, } \\
\text { Loko 2\%, } \\
\text { Other } 15 \%\end{array}$ & $\begin{array}{l}\text { Kpelle } 20 \cdot 3 \%, \\
\text { Bassa } 13 \cdot 4 \%, \\
\text { Grebo } 10 \%, \\
\text { Gio } 8 \%, \\
\text { Mano } 7 \cdot 9 \%, \\
\text { Kru } 6 \%, \\
\text { Lorma } 5 \cdot 1 \% \text {, } \\
\text { Kissi } 4 \cdot 8 \%, \\
\text { Gola } 4 \cdot 4 \%, \\
\text { Other } 20 \cdot 1 \%\end{array}$ \\
\hline
\end{tabular}

percent of tested samples that were EVD positive, and days between symptom onset and case hospitalization) and one showed worse problems in Sierra Leone (number of districts with at least one security incident); the remaining indicators were nearly equivalent (Fig. 3).

\section{Outbreak by country with limited transmission}

EVD cases were exported to seven additional countries and details regarding the country-specific outbreaks are organized by date of first confirmed EVD case. Of these, Nigeria, Senegal, and Mali are West African countries with relatively high potential for ongoing transmission, particularly Nigeria. However, a robust public health response prevented widespread transmission in these countries [12]. The US, Spain, the UK, and Italy also had $\geq 1$ imported EVD case. Only the US reported in-country EVD transmission. All of these countries reported their EVD cases in 2014, except Italy, which was in May 2015. Table 1 summarizes the number of cases, deaths, contacts followed, and date first declared Ebola-free.

\section{Nigeria}

The first case was reported July 20, 2014 in the Lagos District and imported from Liberia [12]. This marks the first recorded time Ebola spread to another country via airline travel.[12]Although the index case in Nigeria transmitted the disease to at least five people who died, no transmission occurred on the flight, despite the infected adult male vomiting enroute [12]. Port Harcourt was Nigeria's second district to be affected with an EVD case reported on August 1. Nigeria was declared Ebola-free on October 20, 2014 with a final case count of 20, eight deaths [8] and $\geq 891$ contacts requiring follow-up [22].

\section{Senegal}

An adult male who travelled by road from his home in Guinea to Dakar was Senegal's only EVD case and reported on August 29, 2014 [12]. He survived and Senegal was declared Ebola-free on October 17, 2014.

\section{United States of America}

On September 30, 2014, the first EVD case in the US was reported in Dallas, TX. An adult male travelling from Liberia developed symptoms four days after arriving and expired on October 8. He transmitted EVD to two female nurses. The first was diagnosed on October 10 and discharged from the hospital on October 24. The second was diagnosed on October 15 and discharged on October 28. She took two flights but no transmission was identified [23]. The fourth case was in a male physician living in New York City who worked with Doctors without Borders. He was diagnosed October 24 and discharged November 11. This physician potentially exposed multiple individuals during the first day of his illness at public places like 


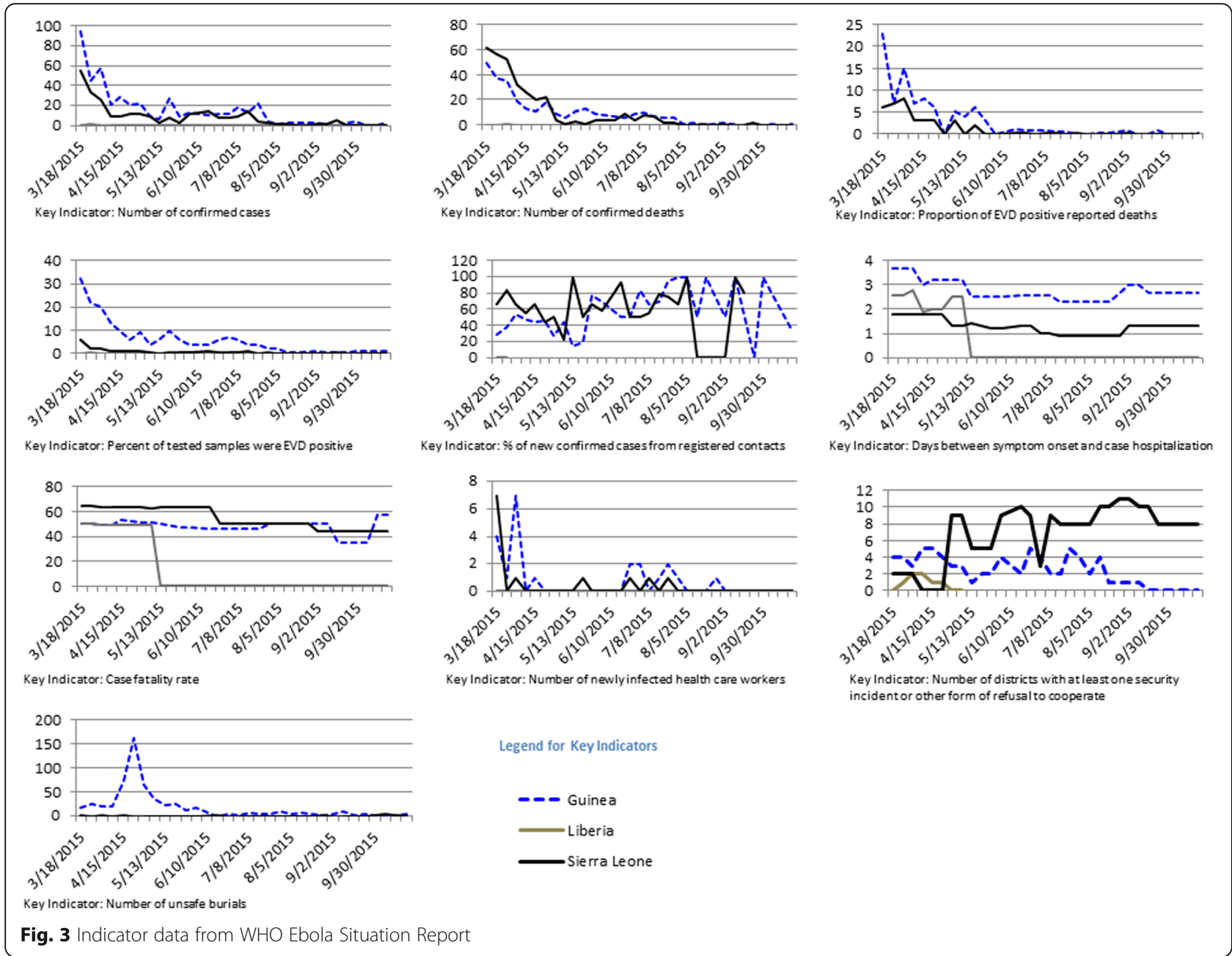

restaurants and a bowling alley, but no transmission was identified [23]. Of these four cases, one died, two were imported, and two were from local transmission [8]. There were an additional six EVD cases acquired in West Africa but treated in the US [24]. Of these, there were three HCWs, an aid worker, a missionary, and a cameraman. All but one recovered. The U.S. was declared Ebola-free on December 20, 2014.

\section{Spain}

An adult male, Spanish HCW was repatriated from Sierra Leone on September 22, 2014 and reported as an EVD case on October 6 [25]. Successful contact tracing of 87 people was conducted and no subsequent transmission was identified. He survived and Spain was declared Ebola-free on December 2, 2014.

\section{Mali}

Health officials in Mali investigated six suspect cases in April 2014 which helped prepare for the introduction of their first confirmed case in October 2014. This EVD case was a two-year-old female from Guinea (reported on October 23) [12]. Being symptomatic during her journey to Mali, the girl died the following day. On October 25, a Grand Imam from Siguiri prefecture in Guinea was admitted to a clinic in Bamako for acute kidney failure. Ebola was not initially recognized and he died on October 27. Because his symptoms began in Guinea, he is reported as a Guinean case. That case led to seven additional cases, with five deaths [12]. By January 18, 2015, when Mali was declared Ebola-free, the final case count was eight with six deaths [8]. Kayes and Bamako were the only districts affected [16].

\section{United Kingdom}

On December 29, 2014 a female HCW returning from Sierra Leone was reported as the only EVD case in the UK [26]. She developed symptoms as she arrived in London. The 177 people on a shared flight were classified by at least one source as exposed contacts, but were 
treated as low risk. All 132 passengers on board the shared flight (AT0800 from Casablanca to London) and crew members were successfully contacted. Public Health England advised passengers sitting in the two rows adjacent (comprising 21 passengers) to take their temperature twice daily for 21 days [27]. The patient survived and there were no additional cases [16].

\section{Italy}

On May 12, 2015, a case of Ebola in a male Italian volunteer HCW was reported. He returned from Sierra Leone on May 7, became symptomatic on May 10, and hospitalized on May 11. No inflight contact tracing was done. There were 19 contacts to this case [18]. On July 20, 2015, Italy was declared Ebola-free having no additional EVD cases and no deaths [28].

\section{Discussion}

WHO declared the Ebola epidemic over on March 29, 2016 with 28,646 cases and 11,323 deaths across 10 countries and three continents. Of the three countries most widely affected, Liberia was first to successfully control the epidemic (February 2015), which was before the key indicator data were collected (March 2015). The epidemic in Sierra Leone and Guinea was largely controlled by April 2015, but experienced sustained transmission into November 2015.

Using the data from the present study, the key indicators that seemed to be substantially different between Sierra Leone and Guinea were 1) the number of unsafe burials, 2) the percent of tested samples that were EVD positive, 3) the number of days between symptom onset and case hospitalization, and 4) the number of districts with at least one security incident. There are a number of additional factors highlighted in the WHO Ebola Situation Reports (and substantiated in the published literature). Burial practices were cited as the single strongest risk factor for transmission; $60-80 \%$ of all cases reported an exposure to a traditional burial [29]. While previous outbreaks were largely controlled by using contract tracing, $[10,30]$ this is the first EVD pandemic with a prolonged duration where treatment and supportive care played an unquantified role in the response [10, 30, 31]. Another key difference was the strong stigma associated with EVD infection in this outbreak as demonstrated by community attempts to hide cases from authorities. These areas came to be known as "shadow zones" [22] and were accompanied by angry mobs attacking health care facilities and workers. The first such occurrence was on April 4, 2014 in Macenta, Guinea, [27] and differences in events between Sierra Leone and Guinea are shown in Fig. 3.

The Pearson correlation estimates were limited by small sample size (three countries). The strongest country-level health indicator was between hospital bed density and the duration of the outbreak $(r=-0.99)$. Increasing bed capacity was shown to contribute to controlling the Ebola pandemic by two modeling studies, [32, 33] however, the belated timing of the escalation of bed capacity likely limited its impact [34]. We suggest that helping countries increase health infrastructure, particularly by having more hospital beds, as well as ongoing infection control training and capacity building, may help combat severe diseases such as EVD. Diagnostic equipment, largely unavailable during the early part of the outbreak, was also key for effective patient management.

This pandemic highlights the need for the international community to respond to transnational outbreaks in a timely manner. Despite the heroic efforts of early responders (e.g., local HCWs, personnel with Médecins Sans Frontières, $C D C$, and others), on a global scale, the response time was inadequately slow. This is possibly due to international politics and the sluggish turning wheels of governments who strive to do the right thing while meeting the needs of their citizens.

The response by the US arguably began in March 2014 when CDC deployed personnel to investigate Ebola cases in Guinea, and further on July 9, 2014 with the activation of CDC's Emergency Operations Center. However, because EVD was largely out of the public's eye until the fall of 2014, its response was similarly delayed. That is, the peak number of EVD cases in Liberia was September 21, 2014; one week after President Obama's announcement to commit 3000 troops and provide additional aid to the Ebola response effort [35] and one month after WHO declared it a public health emergency of international concern. These events unlikely contributed substantially to controlling the EVD pandemic [34]. The US's response was impressive in terms of funding and personnel. By April 2015, the US spent \$1.4 billion on the Ebola response effort. During 2014-2016, the HHS global and domestic response mobilized more than 4000 personnel [36]. Approximately 300 active duty Commissioned Corps officers in the US Public Health Service established, operated and staffed the Monrovia Medical Unit, an Ebola Treatment Unit having more sophisticated medical capabilities than those in conventional Ebola treatment Units. The Monrovia Medical Unit provided advanced supportive care to responders who became ill during this West African crisis and were the only US (non-private) personnel to provide direct patient care to persons infected with EVD.

This study is subject to certain limitations. Perhaps the most substantial of which is the difficulty to quantify many factors affecting control of the outbreak. For example, the West African people educated their communities, facilitating the change of social practices, such as greetings with physical contact and modifying long-standing traditional burial practices [31, 37]. Education messages on fighting the epidemic were communicated through messaging in radio, billboards, etc. 


\section{Conclusions}

In conclusion, the 2014 West African Ebola outbreak devastated three West African countries and propagated to seven additional countries on three continents. The public health response and subsequent control of the outbreak was different across Guinea, Liberia and Sierra Leone. The results from both the analysis of country-level data and the qualitative analysis generate hypotheses that inadequate infrastructure at the country level contributed to the delayed control of EVD within the affected countries and contributed to lower survival rates. This Ebola epidemic, as many in the past (such as HIV, West Nile virus, SARS, and cholera in Haiti), shows us that epidemics can have a devastating global impact, and therefore should be considered everyone's problem. The recent Zika virus epidemic followed many similar patterns highlighting that we all share the responsibility in responding to infectious outbreaks. Many of the country-level factors, particularly the WHO key indicators were associated with controlling the epidemic. International political and public health leaders should assess the infrastructure of countries affected by communicable diseases.

\section{Methods}

We used publicly available data for Guinea, Liberia, and Sierra Leone for the following demographic attributes: 1) population and population density, 2) median age (years), 3) infant mortality rate (deaths/1000 live births), 4) health expenditures (\% of GDP), 5) physician density (physicians/1000 population), 6) hospital bed density (beds/1000 population), 7) literacy (age 15+ can read and write), 8) education expenditures (\% of GDP), 9) urbanization (\% urban), 10) religions (\% distribution), and 11) ethnic groups (\% distribution). Pearson correlations were calculated and associated scatterplots were generated to assess associations between healthcare indicators for each country (health expenditures, physician density, hospital bed density, and infant mortality rate) and the duration of the EVD outbreak (in days) and the EVD-specific mortality rate.

The outbreak-specific data were obtained from the weekly WHO Ebola Situation Reports during which the key indicator data were uniformly published (March 18, 2015-October 21, 2015). Key indicators included 1) number of confirmed cases, 2) number of confirmed deaths, 3) number and proportion of EVD-positive reported community deaths, 4) number of samples tested and the percent of positive EVD results, 5) percent of new confirmed cases from negative contacts, 6) time between symptom onset and hospitalization (in days), 7) case fatality rate among hospitalized cases, 8) number of newly infected health workers, 9) number of unsafe burials and the reported number of community deaths, 10) number of districts with at least one security incident or other form of refusal to cooperate. Line graphs for each key indicator were generated to assess differences between Guinea, Liberia, and Sierra Leone.

We also summarize the impact of EVD in the seven additional countries with limited EVD transmission. The number of cases, deaths, case fatality rate, case-contacts requiring monitoring, date of first EVD case, and date first declared Ebola-free were summarized for each country. Data were collected using Index Mundi, the WHO Situation Reports and Internet searches, focusing on government sources, to identify relevant Ebola-related information within the scope of outcome measures listed above.

\section{Abbreviations}

CDC: Centers for Disease Control and Prevention; EVD: Ebola virus disease; GDP: gross domestic product; HCW: healthcare worker; U.S.: United States of America; UK: The United Kingdom of Great Britain and Northern Ireland; WHO: World Health Organization

\section{Acknowledgments}

This research was supported in part by the Defense Intelligence Agency, Grant \# HHM402-14-1-007 (PI: Regens). The views and conclusions contained herein are those of the authors and should not be interpreted as necessarily representing the official policies or endorsements, either expressed or implied, of DIA, the Indian Health Service, or the US government.

\section{Funding}

Funding was provided through the Defense Intelligence Agency, Grant \# HHM402-14-1-007 (PI: Regens).

\section{Availability of data and materials}

The data are publically available and the sources are referenced within the manuscript. The data collected from the weekly WHO Situation Reports were summarized in an MS Excel file which will be made publically available pending acceptance of the manuscript for publication.

\section{Authors' contributions}

AMW, MM, and JLR contributed to Study conception and design. AMW and MM were primarily responsible for data analysis. All authors contributed to interpreting the data. All authors contributed to the drafting/revising of the manuscript for important intellectual content. All authors have provided final approval of the submitted manuscript. All authors agree to be accountable for the accuracy and integrity of the work.

Ethics approval and consent to participate

Not applicable. We did not seek approval from an ethics board/institutional review board because the data were from publically available sources.

Consent for publication

Not applicable

\section{Competing interests}

The authors declare that they have no competing interests.

The authors declare that the research was conducted in the absence of any commercial or financial relationships that could be construed as a potential conflict of interest.

\section{Publisher's Note}

Springer Nature remains neutral with regard to jurisdictional claims in published maps and institutional affiliations.

\section{Author details}

'Department of Biostatistics and Epidemiology, University of Oklahoma Health Sciences Center, 801 NE 13th St., CHB 323, Oklahoma City, OK 73104, USA. ${ }^{2}$ Center for Intelligence and National Security, University of Oklahoma, 755 Research parkway, Suite 520, Oklahoma City, OK 73104, USA. ${ }^{3}$ Indian 
Health Service, US Public Health Service, 701 Market Drive, Oklahoma City, OK 73114, USA. ${ }^{4}$ National Heart Lung and Blood Institute, Hematology Branch, Section of Transplantation Immunotherapy, National Institutes of Health, Building 10-CRC, Room 3-5330, Bethesda, MD 20814, USA. ${ }^{5}$ Division of Intramural Research, Office of the Clinical Director, National Institutes of Health, Bethesda, MD, USA.

Received: 26 April 2018 Accepted: 11 July 2018

Published online: 27 July 2018

\section{References}

1. Bernard KW. Health and national security: a contemporary collision of cultures. Biosecur Bioterror. 2013;11(2):157-62.

2. Burgess JP. The Routledge handbook of new security studies. London: Routledge; 2010.

3. Aldis W. Health security as a public health concept: a critical analysis. Health Policy Plan. 2008;23(6):369-75.

4. Garrett L. The coming plague. New York: Penguin; 1994.

5. Elbe S. Pandemics on the radar screen: health security, infectious disease and the medicalisation of insecurity. Political Studies. 2011;59(4):848-66.

6. W. H. O. Ebola Response Team. Ebola virus disease in West Africa--the first 9 months of the epidemic and forward projections. N Engl J Med. 2014; 371(16):1481-95

7. Adopting Resolution 2176 (2014), Security council approves threemonth Extention for United Nations mission in Liberia, With further renewal under review [http://www.un.org/press/en/2014/sc11559.doc htm]. Accessed 8 Nov 2016.

8. Ebola Situation Report [http://www.who.int/csr/disease/ebola/situationreports/archive/en/]. Accessed 21 Jan 2015.

9. Ebola Situation Report - 30 March 2016 [http://apps.who.int/ebola/currentsituation/ebola-situation-report-30-march-2016]. Accessed 8 Nov 2016.

10. W. H. O. Ebola Response Team. After Ebola in West Africa--unpredictable risks, preventable epidemics. N Engl J Med. 2016;375(6):587-96.

11. Meltzer MI, Atkins CY, Santibanez S, Knust B, Petersen BW, Ervin ED, Nichol ST, Damon IK, Washington ML. Estimating the future number of cases in the Ebola epidemic--Liberia and Sierra Leone, 2014-2015. MMWR Suppl. 2014;63(3):1-14.

12. One Year into the Ebola Epidemic: a Deadly, Tenacious and Unforgiving Virus [http://www.who.int/csr/disease/ebola/one-year-report/introduction/en/]. Accessed 8 Nov 2016.

13. Saez A, Weiss S, Nowak K, Lapeyre V, Zimmermann F, Dux A, Kuhl H, Kaba $M$. Investigating the zoonotic origin of the west African Ebola epidemic. EMBO Mol Med. 2015;7(1):17-23.

14. Vogel G. Bat-filled tree may have been ground zero for the Ebola epidemic. Science. 2014;12

15. Hersey S, Martel LD, Jambai A, Keita S, Yoti Z, Meyer E, Seeman S, Bennett S, Ratto J, Morgan O, et al. Ebola virus disease--Sierra Leone and Guinea, august 2015. MMWR Morb Mortal Wkly Rep. 2015;64(35):981-4.

16. CDC classification of countries with reported Ebola cases for evaluation of persons in the United States [http://www.cdc.gov/vhf/ebola/outbreaks/ 2014-west-africa/distribution-map.html\#areas]. Accessed 22 Jan 2015.

17. Ebola Situation Report - 2 March 2016 [http://apps.who.int/ebola/currentsituation/ebola-situation-report-2-march-2016]. Accessed 8 Nov 2016.

18. Ebola Situation Report - 20 May 2015 [http://apps.who.int/iris/bitstream/handle/ 10665/171812/roadmapsitrep_20May15_eng.pdf;jsessionid=B22C4598CDCC406 CB7CEA8CD44C0D52C?sequence=1]. Accessed 22 May 2015.

19. WHO Strategic Action Plan for Ebola Outbreak Response: Annex 1 [http://www.who.int/csr/disease/ebola/evd-outbreak-response-plan-westafrica-2014-annex1.pdf]. Accessed 8 Nov 2016.

20. Resources for Results V: 1 September 2014 to 31 October 2015 [https:// ebolaresponse.un.org/sites/default/files/resources_for_results_v.pdf]. Accessed 8 Nov 2016

21. Fact Sheet \#9, Fiscal Year 2016 [https:/www.usaid.gov/sites/default/files/ documents/1866/west_africa_ebola_fs09_03-24-2016.pdf]. Accessed 13 Apr 2016.

22. WHO: Ebola Response Roadmap Update [http:/apps.who.int/iris/bitstream/ 10665/136645/1/roadmapupdate17Oct14_eng.pdf?ua=1]. Accessed 17 Oct 2014.

23. Cases of Ebola Diagnosed in the United States [http://www.cdc.gov/vhf/ ebola/outbreaks/2014-west-africa/united-states-imported-case.html]. Accessed 22 Jan 2015.

24. Ashkenas J, Buchanan L, Burgess J, Fairfield H, Grady D, Keller J, Lai KKR, Lyons PJ, Murphy H, Park H, et al. How many Ebola patients have been treated outside of Africa? New York: In: New York Times; 2015.
25. WHO Congratulates Spain on Ending Ebola Transmission [http://www. who.int/mediacentre/news/statements/2014/spain-ends-ebola/en/]. Accessed 15 Jan 2015.

26. Ebola Virus Disease - United Kingdom [http://www.who.int/csr/don/30december-2014-ebola/en/]. Accessed 22 Jan 2015.

27. Public Health England Completes Ebola Contact Tracing [https://www. gov.uk/government/news/ebola-contact-tracing-underway]. Accessed 22 Jan 2015.

28. Ebola Situation Report - 22 July 2015 [http://apps.who.int/ebola/currentsituation/ebola-situation-report-22-july-2015]. Accessed 8 Nov 2016.

29. World Health Organization. Factors that contributed to undetected spread of the Ebola virus and impeded rapid containment. In: One year into the Ebola epidemic. Geneva: World Health Organization; 2015.

30. Frieden TR, Damon I, Bell BP, Kenyon T, Nichol S. Ebola 2014--new challenges, new global response and responsibility. N Engl J Med. 2014;371(13):1177-80.

31. Coltart CE, Lindsey B, Ghinai I, Johnson AM, Heymann DL. The Ebola outbreak, 2013-2016: old lessons for new epidemics. Philos Trans R Soc Lond Ser B Biol Sci. 2017;372(1721)

32. Kucharski AJ, Camacho A, Flasche S, Glover RE, Edmunds WJ, Funk S. Measuring the impact of Ebola control measures in Sierra Leone. Proc Natl Acad Sci U S A. 2015;112(46):14366-71.

33. Townsend JP, Skrip LA, Galvani AP. Impact of bed capacity on spatiotemporal shifts in Ebola transmission. Proc Natl Acad Sci U S A. 2015;112(46):14125-6.

34. Kirsch TD, Moseson H, Massaquoi M, Nyenswah TG, Goodermote R, Rodriguez-Barraquer I, Lessler J, Cumings DA, Peters DH. Impact of interventions and the incidence of ebola virus disease in Liberiaimplications for future epidemics. Health Policy Plan. 2017;32(2):205-14.

35. Onishi N. Empty Ebola clinics in Liberia are seen as misstep in U.S. relief effort. In: The New York times; 2015.

36. Frieden TR. Foreword. MMWR Suppl. 2016;65(3):1-3.

37. Wilkinson A, Parker M, Martineau F, Leach M. Engaging 'communities': anthropological insights from the west African Ebola epidemic. Philos Trans R Soc Lond Ser B Biol Sci. 2017;372(1721)

38. Ebola Situation Report [http://www.who.int/csr/disease/ebola/situationreports/en/?m=20150114]. Accessed 14 Jan 2015.

39. WHO: Ebola Response Roadmap Situation Report [http://apps.who.int/iris/ bitstream/10665/133833/1/roadmapsitrep4_eng.pdf?ua=1]. Accessed 18 Sept 2014.

40. Ebola Situation Report - 17 December 2014 [http://apps.who.int/ebola/en/ status-outbreak/situation-reports/ebola-situation-report-17-december-2014]. Accessed 17 Dec 2014.

41. Index Mundi [http://www.indexmundi.com/factbook/compare/guinea. liberia/demographics]. Accessed 5 June 2015.

Ready to submit your research? Choose BMC and benefit from:

- fast, convenient online submission

- thorough peer review by experienced researchers in your field

- rapid publication on acceptance

- support for research data, including large and complex data types

- gold Open Access which fosters wider collaboration and increased citations

- maximum visibility for your research: over $100 \mathrm{M}$ website views per year

At $\mathrm{BMC}$, research is always in progress.

Learn more biomedcentral.com/submissions 